\title{
A crise da prisão e as prisões abertas $(*)$
}

\author{
Astor Guimarães Dias \\ Promotor Público. - Presidente da "Sociedade Brasileira \\ de Criminologia e Ciência Penitenciária".
}

A história da evolução da pena obedece a várias etapas, no decorrer do século.

No início era a vingança brutal e instintiva exercida pelo ofendido contra o primeiro que encontrasse, ou particularmente, contra o ofensor. É o período da vingança privada, que, se divide em indireta ou direta, conforme a proposta de Steinmetz, indireta se é dirigida contra qualquer um, direta se dirigida especificamente contra o ofensor.

Mais tarde já desenvolvidos os sentimentos de solidariedade familiar, a vingança passa a ser exercida pelo ofendido e sua família, contra o of ensor, que conta com a solidariedade de seus familiares. Resultaram dessas manifestações de solidariedade ao ofendido e ao ofensor, inúmerós conflitos, que ensanguentaram as épocas primitivas e estinguiram numerosas famílias. E o periodo da vingança familiar.

E nesse estágio do direito penal, que existem o talião e a "compositio". O talião consagrado no "Êxodo" -

"Reddes animam pro anima, oculum pro oculo, dente pro dente, manus pro mana, pede pro pede, adustionem pro adustione, vulnus pro vulnere, livro pro livore."

(*) Trabalho aprovado na "IV Reunião Penitenciária Brasileira" - 1955 - Belo Horizonte - 2.0 lugar e Menção Honrosa no Prêmio "Oscar Freire" (Criminologia - 1955.) 
A "compositio" traduzida na remuneração pecuniária do ofensor à vítima, onde se pode lomigar o germe do instituto da indenização. Eram frases primitivas da pena, mas é oportuno lembrar, que alguns autores, entre êles Azevedo Franco, vêm no talião, um grande avanço para a época, "porque veio estabelecer entre a ofensa e a reação, uma proporção, uma equivalência, que não existia na vingança privada, na fase anterior." (1)

Aos poucos porém, foi ganhando corpo a idéia de que ao Estado competia a aplicação do direito de punir, exercido como autêntica vingança pública. Entrava a humanidade, criminològicamente falando, na fase social da pena. Durante séculos todavia, essa manifestação do Estado no campo punitivo, se faz sentir de novo violento e cruel. Penas, como o esquartejamento, a morte pelo fogo, a decapitação, a roda, eram comumente aplicadas. Os violentos castigos corporais, as amputações, as torturas, encontravam freqüentes aplicações.

É na segunda metade do século xviı que surge o primeiro grande movimento de humanização das penas, que teve como Bíblia, o livro de Beccaria - "Dei delliti e delle pene". Beccaria revolucionàriamente pregava a desaparição da desigualdade das penas. Traça regras para preciação das provas dos delitos, combate as penas e cuida da divisão dos delitos. De sua obra, pequena, - mas monumental, parte o grito de humanização das penas, com o qual irão fazer côro inúmeros juristas, entre os quals o ilustre Filangieri na Itália, o que motivou a frase de Prins:

"En Italie, Beccaria et Filangieri èmeuvent les penseurs par l'accente sincère de leur enthousiasme humanitaire". (2)

(1) Ary Azevedo Franco - "Direito Penal" - 1. a parte, pâg. 436 - Ed. Almeida Marques.

(2) Adolphe Prins - "Science Pénale et Droit Positif" - pág. 11 Ed. Chevalier Marsq - París, 1899. 
É ainda na Itália, que surge, ligada sua origem, à obra de Beccaria, a primeira grande escola do Direito Penal a Escola Clássica. Foi Carmignani em seu grandioso "Programa del corso di diritto criminale" resumiu os princípios da escola, num estudo imperecível de todo Direito Penal. $\mathrm{Na}$ Escola Clássica enfileiram-se penalistas do porte de Rossi, Pessina e Faustin Hélie.

Assentam os clássicos a responsabilidades penal, no princípio do livre arbítrio, e que assenta a responsabilidade, no princípio da responsabilidade social. O homem é responsável porque é imputável, e essa imputação resulta de sua vivência em sociedade. A Escola Positiva dedica ao criminoso, a atenção que a Escola Clássica deixara de dedicar. Foi Cesare Lombroso, o pontífice da Escola Positiva. Sôbre sua presença, na ciência penal, colocando-o frente a Beccaria diria o eclético Van Hamel:

"Nos tempos da prepotência e do arbitrio, César Beccaria disse ao homem - Homem, conhece a justiça. Outro César (Lombroso), um século mais tarde, voltando-se à justiça, declarou: - Justiça, conhece o homem!"

Voltando-se para o estudo profundo do homem, criou Lombroso a teoria do criminoso nato, que marcaria época na ciência penal, que seria um dos ramos na árvore classificacional dos criminosos, plantada por Ferri. Ferri e Garófalo, com seus trabalhos imperecíveis seriam dois nomes refulgentes da Escola Positiva.

Conciliando as tendências da Escola Clássica e da Escola Positiva, surgiria na Itália a chamada "terza-scuola", de Alimena e Carnevali, e ainda numa posição conciliatória apareceria o trabalho de Garraud e Tarde na França, e surgiria a "Escola da Política Criminal", que apresentaria como nomes estelares Von Liszt, Prins e Van Hamel. Os ecléticos, de um modo geral peferiam o método indutivo da Escola Positiva, ao método dedutivo usado pela Escola Clássica. Ainda em consonância com a Escola Positiva afirmariam a necessidade de investigações antropológicas. 
Mas, discordariam de Lombroso, quanto à criminalidade congênita e considerariam juridicamente o delito, à feição da Escola Clássica.

Outras tendências penais, se fizerem sentir entre os jurístas, como a tendência idealista, de Croce e Gentile, reagindo contra a Escola Antropológica, a "Escola Penal Humanista", de Lanza e Falchi, que subordina o Direito Penal à moral; a "Escola Técnico Jurídica" da Manzini e Rocco, que chama atenção para o estudo do Direito Penal vigente o que prega a necessidade da criação de um Direito Penal autônomo; a "Escola Pragmática" de Quintiliano Saldanã, e que procura basear a política criminal nos dados da experiência e a Escola Penal Humanitária, que visava conciliar o tecnicismo jurídico e as novas conquistas da Escola Positiva, e que teve em Sabatini, o seu fundador. (3).

\section{O fundamento filosófico da pena}

Questão de relevância, é saber em que se funda o direito de punir?

Qual o fundamento filosófico da pena imposta ao delinqüente?

Três direções, podem ser observadas, nos caminhos seguidos pelos penalistas e filósofos, que procuraram resolver o problema. Primeiro; aquela em que se enfileiraram as chamadas doutrinas absolutas, morais, metafísicas, ou subjetivas.

Segundo; as constituidas pelas doutrinas relativas utilitárias, econômicas, ou objetivas. Terceiro; a das doutrinas ecléticas ou mistas.

Para as doutrinas absolutas, expressas na máxima "punitur quia peccatum est", a pena é justa em si mesma,

(3) Basileu Garcia, "Instituições de Direito Penal" vol. I, Tomo I, Capítulo IV - Ed. Max Limonad, 1.051 - São Paulo. 
o criminoso é punido porque pecou. A pena é o justo castigo, a merecida provação que recebe aquêle que delinqüiu.

Segundo Azevedo Franco, apresentam essas doutrinas três fases:

a) Fase expiatória em que se pune o delinqüente porque pecou.

b) Fase retribuitiva, desagregação da fase expiatória, mas em que já se tinha uma concepção menos subjetiva, em que o crime não é mais pecado, e que florece nos fins do direito canônico.

c) Fase intimidativa, em que se atribui à pena um aspecto intimidativo, em que a pena é como uma advertência, tendente a evitar que outros venham a delinqüir.

Entre as teorias absolutas, não pode ser esquecida a do genal Emanuel Kant. Partindo de sua doutrina filosófica e das idéias de Rousseau, admitia Kant, que a pena é um imperativo categórico, um imperativo que não aceitava condicionalidade, e que visaria espiar o mal pelo próprio mal. A finalidade da pena não é corrigir, mas de expiar o mal pelo próprio mal.

Para as outras doutrinas relativas, o fundamento da pena não residia no elemento moral, mas na utilidade social da pena. A pena é legítima, porque é útil ao agrupamento social. As doutrinas relativas, exprimem-se pela máxima "Punitur ut ne peccetur" e em sua evolução, conforme o citado Azevedo Franco, encontramos três fases a primeira em que a pena é um direito defensivo da sociedade, a sociedade pune para se defender; a segunda, em que a sociedade pune para intimidar; a terceira em que a sociedade punindo, busca a regeneração do criminoso.

Já Platão e Aristóteles haviam esboçado a doutrina da vantagem social da pena. Para Welcker, a capacidade punitiva do Estado resultaria da necessidade de fazer cessar o alarma decorrente do crime, para Carmignani o fundamento de punir resultaria da necessidade da conservação 
da ordem social, doutrina que seria aprimorada pelo grande Carrara. Ainda dentro do grupo das teorias relativas, lembraríamos Hobbes e Ortolan, que fundamentavam a pena na utilidade social, Haus que lhe dava como fundamento a necessidade de manter a ordem social e Bentham, que a fundamentava no interêsse público.

Finalmente, as doutrinas mistas acham que a pena é um castigo, com função retribuitiva, mas também possui finalidade utilitárias, como a educação, a correção e a intimidação.

É o maior nome dessas doutrinas, Pellegrino Rossi, seguido por Guizot, Broglie, Jouffroy, Cousin e outros, que defendem o que o Estado pune "quia peccatum est est ut ne peccetur".

\section{A evolução dos sistemas penitenciários}

A pena de prisão deve sua origem, conforme a lição de Prins, a dois fatos - a convição de que as crueldades impostas aos condenados, não diminuiam o desenvolvimento da criminalidade e o desejo de retirar do condenado uma utilidade econômica. A Idade Média, como a antiguiade conhecia lugares de detenção, como os castelos fortes os subterryneos das hospedarias das cidades. Mas é no século XVI, que sürgem as primeiras "maisons de force", onde eram recolhidos os mendigos, os vagabundos e as prostitutas, obrigando-os ao trabalho. Surgem as "maisons de force", em Londres (1550), Nuremberg (1558) e Amsterdan (1595). No século XVIII, todavia, são organizados estabelecimentos de detenção, como os Gaols ou Bridewells, na Inglaterra; os Zucht Raspal ou Spinnhauser na Alemanha e Holanda e os Gagnes na França. Esses presídios não se erigem sôbre a preocupação de um regime carcerário, não há preocupação de higiene, moralidade ou correção.

Comentando o estado dessas prisões, escreve o citado Prins: 
"Les detenus sont entassés pêle-Mêle das urie promiscuité révoltante; ils sont soubis ao régime le plus dur, subssent des penes disciplinaires corporelles, sont astreins à des travaux punibles. Ils ne recoivent qu'un minimun de nourriture (du pain et de l'eau); ils sont parfois chargés de chaines et le manque d'ais, d'alimentation et des soins élémentaires de propreté est tel que des fiévres infectueuses, se dèveloppement à l'interieur des prisons, y déciment la population se propagant au dehors et font des ravages dans la population libre" (5).

A ciência penitenciária ainda gatinhava. Contudo, já a prisão de Amsterdan apresentava boas condições de disciplina, e separava os detentes de noite, e os espíritos esclarecidos e bondosos se preocupavam com a sorte dos presos, sendo bister salientar os esforços de S. Vicente da Paula, em 1619. Em 1677 na prisão de Franci, em Florença, já havia a separação de criminosos; em 1703, sob as ordens do Papa Clemente XI, uma parte do hospício de S. Miguel é destinada ao recolhimento de delinqüentes menores de vinte e um anos. Mas o regime penitenciário, na acepção exata do têrmo, só aparece em $1776 \mathrm{com}$ a famosa prisão de Cand, na Bélgica, onde havia trabalho em comum durante o dia, o silêncio e o isolamento durante a noite, e uma classificação dos criminosos.

O primeiro grande sistema penitenciário surge nos Estados Unidos, em Filadélfia, como conseqüência da repercussão do livro de John Howard - "The State of Modern Prisons" e tomou o nome de sistema pensilvânico ou filadélfico. Era caracterizado pelo isolamento celular absoluto, não havia comunicação do prêso com o mundo exterior, e o condenado só recebia visitas do capelão, do guarda e do diretor da prisão. Era o sistema de isolamento absoluto, extremamente severo.

(5) Adolphe Prins - Obra citada - pág. 432. 
Tendente à amenização do sistema filadélfico, surge posteriormente ainda nos Estados Unidos, o sistema suburneano, praticado na cidade de Auburn. No sistema suburneano, durante o dia havia o trabalho em comum, e a segregação celular só se verificava à noite. I sistema suburneano revivia em suas linhas gerais, o regime penitenciário da antiga prisão de Cand. Entretanto, êsse sistema, tornando obrigatório o silêncio, durante o trabalho em comum diurno, era também rigoroso em demasia para o encarcerado.

Procurando suavizar os rigores dos precedentes sistemas, surgiu na Inglaterra nos fins da primeira metade do século XIX, o sistema progressivo, ou "mark system", como o chamavam os inglêses. O cumprimento da pena era dividido em três estágios - no primeiro período relativamente curto, aplicava-se o regime filadélfico, havendo a segregação diurna e noturna. No segundo estágio era aplicado o regime suburneano, com isolamento noturno, e trabalho diurno em comum, debaixo de silêncio. Finalmente, o terceiro estágio constituia a grande inovação do sistema, era o período de liberdade condicional, em que o condenado de bom comportamento, que se manifestasse apto à vida social, viveria em liberdade em lugar determinado e fiscalizado pela polícia.

O sistema progressivo, criação de Machonochie foi aplicado com grande êxito e mereceu louvores de estudiosos da matéria, como Prins, e Tarde. Na Irlanda Sir Walter Crofton, introduz entre a segunda e terceira fase, do regime progressivo, uma outra, que é a do recolhimento intermediário em penitenciárias agrícolas ou industriais. $\mathrm{O}$ sistema progressivo passa desde êsse instante a ser conhecido também, como sistema irlandês.

Na segunda metade do século XIX, surge no Estado de Nova Iorque o reformatório de Elmira, que aperfeiçoa o regime progressivo. O sistema do reformatório de Elmira escreve Cuello Calón é o mais perfeito sistema penitenciário, e está baseado no princípio da ajuda em substi- 
tuição ao castigo, no da sentença indeterminada, em vez do prazo fixo e no propósito de reabilitar o delinqüente, em vez de apenas o castigar e intimidar. (6) Com o reformatório de Elmira o regime penitenciário atinge a sua melhor expressão. É essa, em traços gerais a evolução dos sistemas penitenciários.

\section{A crise das prisões}

$\mathrm{O}$ século $\mathrm{XX}$ viu nascer um grande movimento humanizador das penas de prisão, movimento que buscava e busca proporcionar ao condenado, condições mais humanas de existência carcerária, ressaltando a dignidade do prêso, que encarcerado embora, não se anula como homem, e um dia, resgatada sua culpa deverá voltar ao convívio dos homens livres.

Esse movimento crítico e constrativo, a um tempo, ganha hoje, uma notória expressão, e os penitenciaristas conjụgam seus esforços visando contemplar os reclusos com um tratamento menos áspero e mais digno.

Já em 1907, João Gonçalves, médico português, lançava o brado - "Há uma grande obra de justiça, de humanidade, a fazer sem delongas: é a de acabar com as Bastilhas penitenciárias"

Na França, a grande voz de Donnedieu de Vabres aponta os malts da pena de prisão, afirmando que ela deprime física e moralmente, e Cremona diretor de um manicômio judiciário na Itália, chama a prisão celular de chaga gravíssima, que ameaça a vida do detento. Ferri, tempos antes pronunciara a frase famosa: - “A cela é uma das aberrações do século XIX”. Ferri atacando dessa forma o regime da segregação absoluta do sistema filadélfico, iniciava uma tenaz campanha contra a cela, campanha que influ-

(6) Cuello Cálon - "Penologia" - pág. 121-Ed. Rens, Madrid -1920 . 
enciou fortemente o sistema auburneano e repercutiu no sistema de Crofton. As idéias de Ferri influenciaram legislações, o exemplo próximo disso, é o atual Código Penal Brasileiro de 1940, que tem uma forte tendência limitativa do uso da cela.

$\mathrm{Na}$ Bélgica, Vervaeck na grande reforma penitenciária de que foi o corifeu, procura reduzir quanto possível o uso da cela, e na Itália, Rocco em seus relatórios ministeriais diz:

"Acreditava-se que a solidão forçaria o homem à meditação e a um recolhimento quase místico, mas teve-se de reconhecer que ela reforçava as predisposições anti-sociais do condenado, tornando mais penosa e mais difícil a sua readaptação à vida social". (7)

Jimenez de Asúa, não tem rebuços em dizer, que a prisão de hoje á mais uma escola de crimes, que uma casa de emenda. Longe de construir, destrói, longe de regenerar, corrompe. Longe de estirpar as tendências criminosas, engrossa-as, desenvolve-as e faz com que os impulsos criminosos recônditos venham à tona, na maré montante da revolta do encarcerado contra a rudeza do regime.

Luís Pinto de Toledo, em excelente trabalho, focaliza os males do isolamento celular:

"O isolamento celular parece agir de maneira mais ou menos semelhante à que Kraepelin assinala em relação aos condenados à longas penas. O prêso sente-se escravo, sem vontade própria tendo apenas consciência da submissão incondicional, debaixo da fôrça do estado onipotente. Sente-se sob um constrangimento que dirige seus atos, e mesmo seu pensamento, dia a dia, por caminhos monótonos, com despotismo inexorável." (8)

(7) Basileu Garcia - obra citada - vol. 1, tomo II, pág. 436.

(8) Luís Pinto DE Toledo - "As psicóses da prisão", — in arquivos de Medicina Legal e Identificação "ano - IV - n. ${ }^{\circ}$, pág. 200 - Rio de Janeiro - 1934. 
E êsse constrangimento implacável, duro e frio, que o levará à revolta, e fará com que nêle surjam os estados psicóticos. Êsse constrangimento, que pesará sôbre seu espírito como uma lage bruta esmagará as possibilidades de regeneração, e fará com que êle saia do ergásgulo, mais criminoso do que quando entrou.

Cesar Salgado, com sua autoridade de penitenciarista esclarecido, criticou de modo candente:

"O regime penitenciário brasileiro, por incrivel que pareça, ainda não conseguiu abolir o isolamento celular. Embora se proclamem com ditirambos as excelências de vários de nossos estabelecimentos penais, a realidade é que, em todos êles vigora o regime da segregação celular do prêso." (9)

Mariano Ruiz Funes, o grande mestre, que ao lado do eminente Benigno de Tullio, nos prolecionou um curso de "Criminologia", em 1947, escreveu sôbre as crises nas prisões, um livro, que já se tornou clássico no assunto. Estudou a pena sob os mais variados aspectos, examinou o personalismo e o transpersonalismo da pena, contemplou a antropologia criminal penitenciária e o exame criminológico, estudou o tormento do silêncio, e o tormento da solidão. Fêz uma análise minuciosa e profunda de todos os problemas do cércere, para penúltiga página de sua obra notável, concluir decididamente:

"A prisão debilitou a vontade; ensinou a preguiça, dispersou as fôrças dos músculos, tornando-as rebeldes a tôda disciplina; criou uma tendência para o esquecimento, o esquecimento, o esquecimento da sua sucessão de maus momento, que ataca ao mesmo tempo a memória e a atenção; permitiu com os seus ócios e o seu forçado culto do afã de evadir, os desvios da fantasia; favoreceu os mitos liber-

(9) César SAlgado - "O Regime Penitenciário Brasileiro" Um êrro que parmanece" - in "justitia" ano VIII — vol. XIII pág. 'T0 — São Paulo — 1952. 
tadores; destruiu os afetos; ampliou o campo das indecisões; aniquilou a sociabilidade. Belas perspectivas para o futuro do sentimento de comunidade, ao retornar à vida livre". (10)

Já muito antes, contudo, em 1918, Anchorana, havia usado a expressão - a crise da repressão - em seu trabalho "La prevención de la delincuencia".

Noé de Azevedo, em estudo apresentado na "IV Jornada Franco-Latino-Americana de Direito Comparado", noticia as críticas de Barnes e Teeters "(New Horizons in Criminal)" e dos Glueck, ao regime penitenciário. (11)

Teodolindo Castiglione e nos dá informes sôbre as críticas de Ataliba Nogueira, Cândido Mendes de Almçida e Plínio Barreto, em trabalho que apresentou na "IV Jornada Franco-Latino-Americana de Direito Comparado", realizada em S. Paulo, no ano de 1954. (12)

\section{A dignidade do prêso}

A prisão no sentido filadélfico, auburneano o mesmo no progressivo irlandês, está em crise. Crise determinada pela preponderância que ganhou nesses sistemas o aspecto retributivo da pena, em detrimento de aspecto regenerativo. A moderna orientação penitenciária não permite mais que veja a pena primordialmente como um castigo, mas ensina, que a pena é um instrumento de recuperação, o meio de que se servirá a sociedade para recuperar o transgressor,

(10) Mariano Ruiz Funes - “A crise nas prisões”, pág. 206, Ed. Saraiva - São Paulo - 1953.

(11) NoÉ DE AzEvedo - "A crise da prisão e os estabelecimentos abertos" - págs. 2 e 3 - São Paulo - 1954.

(12) Teodomiro Castiglione - "A crise da prisão e os estabelecimentos abertos", pág. 4, - S. Paulo - 1954. 
a trombeta que fará soar o pastor, para que volte ao aprisco a ovelha transviada. A pena longe de se despersonalizar, longe de aniquilar, deve reerguer.

Não pode, sob pena de fugir à sua finalidade, o regime penitenciário rebaixar, diminuir, estigmatizar o prêso. Concepción Arenal, a grande penitenciarista de Madrid, que fêz de todos os encarcerados, sua imensa prole, antes do dealbar do nosso século, já ensinava:

"No obstante, en aquel hombre tan sujeto, al parecer tan abrumado por el yugo de la disciplina, que por todas partes le hace, ver los estrechos limites de su cautiverio, hay una coesa libre, el espiritu" (13).

É no espírito livre que irão repercutir as conseqüências do tratamento penitenciário, fazendo do criminoso um revoltado, enchendo-o de rancores e despertando-lhe uma sêde de vingança assoberbante e incontrolável. Há no fundo de tôda alma, por menos meritória que seja, uma parcela de dignidade indestrutível. É tarefa dos penitenciáristas descobrirem essa parcela, êsse talvez "quantum minimum", para fazê-lo crescer, avultar, ganhar expressão.

Para os estudiosos desapaixonados dos problemas penitenciários, o livros das peias doutrinárias rígidas, não surpreendeu o excelente resultado conseguido pela audaciosa experiência do ilustre penitenciarista, Dr. João Carlos da Silva Teles, diretor-geral do Departamento de Presídios de São Paulo, em 24 de janeiro de 1955. Permitiu o citado diretor, que naquela data, 51 presos da "Penitenciária do Estado de São Paulo", usufruissem por 24 horas, da mais completa liberdade, sem vigilância de qualquer espécie. Entre êles se encontravam vários delinqüentes perigosos, condenados a longas penas, e que já haviam tentado fugas, mais de uma vez. Nenhum caso de evasão se verificou. Todos regressaram à Penitenciária. Abordado

13) Concepción Arenal - in "Estudios Penitenciários" Ed. Victoriano Suarez, 2.` Vol., pág. 209 - Madrid. 
pela reportagem de um matutino, um dos presos beneficiados, Joaquim de Carvalho, respondeu que: - "fugiu quatro vêzes por revolta, agora porém que pela primeira vez lhe dispensavam confiança, não podia trair essa confiança." (14)

Era a parcela indestrutível de dignidade, que ganhava expressão, avultava, crescia, impedindo que aquêle que rompera as barras, que escalara os muros para fugir, pudesse violar a palavra empenhada, que poderia nada valer para a sociedade que o encarcerára mas que êle sabia, valia muito para o diretor que lhe permitira um dia de liberdade.

E uma vez mais, foi ouvida a palavra de Concepción Arenal:

"La lección teórica dada al recluso debe ir acompanãda de la moral practicada en derredor suyo por él mismo. Como se le ensenãra con dureza e que no sea cruel, con injusticia a que sea justo; con desprecio a que sea digno, ni con el odio el amor, nila abnegación con él egoismo?" (15)

O prêso tratado com dignidade, responderá com dignidade. Haverá casos de irredutíveis e habituais. É questão apenas, de descobrir como acordar a dignidade adormecida. Um tratamento penitenciário humano e justo, evitará que se repita a sátira feita por um prêso, no sẻculo XIX, dirigida a outro prêso, e recolhida por Lombroso:

"Adiós, Hector; Aquiles te saluda. El que es pobre paga por todos. Las prisones celulares son el refinamiento de la barbarie en pleno siglo XIX". (16)

(14) Jornal "Folha da Manhã" - São Paulo - 26 de janeiro de 1955.

(15) Concepción Arenal - in "Revista de la Escuela de Estudios Penitenciários" - n. 53 - pág. 3 - Madrid - Agosto de 1949.

(16) Lombroso - Los criminales" - pág. 92 - Editorial Tor - Buenos Aires - 1943. 
Nem levará mais, eruditos como Noé de Azevedo, a escrever trabalhos como "O fundo de vingança da Penologia Moderna" abrigando idéias de Ruiz Funes e de Bar. nes e Teeters.

\section{As prisões agrícolas - no estrangeiro - no Brasil. - Penitenciária de Neves}

A grande campanha lançada por Ferri contra a cela viria fomentar o aparecimento das prisões agrícolas, de trabalho "all'aperto", na expressão italiana, que representavam um passo em direção às prisões abertas. Ferri, o grande propugnador, achava que o sol era o grande desinfetante físico e moral. Mesmo Crofton aperfeiçoando o sistema Irlandês, pôs a penitenciária agrícola em certa fase do processo recuperativo do criminoso. Achava Crofton, que o prêso depois de haver cumprido parte da pena em penitenciária industrial, deveria, pelo menos por seis meses, ser encaminhado às penitenciárias agrícolas. $\mathrm{O}$ trabalho em contacto com a natureza é revitalizante física e moralmente. Êsse trabalho, contudo, deve ser um prêmio, conforme ensinava Dvorzak, ao esfôrço tendente a obter o aperfeiçoamento moral.

Não há penitenciárias exclusivamente agrícolas, tendo tôdas as grandes penitenciárias agrícolas, seccões industriais, ensina o mestre das "Instituições de Direito Penal".

O Código Penal de 1940 encarou a reclusão em estabelecimentos agrícolas como um prêmio e estatuiu em seu artigo $30, \S 2 .^{\circ}$, que "O recluso de bom procedimento pode ser transferido para colônia penal ou estabelecimento similar - I - se já cumpriu metade da pena, quando esta é superior a três anos". E o art. 5 . $\S$ único do Decréto-lei n. ${ }^{\circ}$ 3688 de outubro de 1941, assim dispôs:

“Poderão ser transferidos para penitenciária agrícola, da Ilha Grande, que passa a denominar-se - Colônia Penal Cândido Mendes — os reclusos de bom procedimento que: 
- a) já tiverem cumprido a metade da pena, se condenados a reclusão por tempo igual, ou, inferior a três anos: b) ou dois terços da mesma pena, se condenados a reclusão por mais tempo"

Basileu Garcia, em suas "Instituições de Direito Penal" nos dá noticia das penitenciárias agrícolas. Kellerhals, na Suíça, fêz com que os detentos construíssem sôbre um pântano drenado, a famosa prisão de Witzwill, que se mantém com seus próprios recursos. O exemplo de Witzwill impressionou o mundo todo, e os Estados Unidos copiaram o modêlo suíço, edificando o presídio de Indianawitzwill. O mesmo sistema foi seguido pela "State Farm Prisons".

A penitenciária de Witzwill tem seções industriais, onde são fabricadas as cousas que o recluso necessita-móveis, vestuários, etc. Não é pois exclusivamente agrícola.

A Argentina também decidiu tentar as prisões de trabalho "all'aperto". Anchorena, impressionado com Witzwill, pronuncia o discurso de inauguração da "Colônia Penitenciária de La Pampa", primeira penitenciária agrícola portenha, e sôbre cujos resultados, basta transcrever a opinião de B. Gereda:

"La experiencia recogida con el regimen de trabajo a campo abierto es excelente. Durante los nueve anõs que lleva funcionando el establecimiento no se ha habido un intento de evasión" (17).

Portugal foi outro país que recebeu a lição do trabalho penitenciário "all’aperto". Na "Colônia Penal Agrícola de Sintra" e na "Colônia Penitenciária de Alcoentre", repercute o exemplo de Witzwill. Em Alcoentre, o trabalho é realizado em equipes, e a colônia produz vinho e azeite, dedicando-se também à criação de suínos e bovinos.

(17) B. GEREdA - Un establecimiènto modelo: La Colônia de Santa Rosa (La Pampa) - in "Revista de la Escuela de Estudios Penitenciários" - ano V, n. ${ }^{\circ} 51$ - Madrid - julho de 1949. 
O Brasil também acolheu as mesma idéias, e a "Penitenciária Agrícola de Neves" desde logo se tornou famosa. Em nosso país, várias são as penitenciárias agrícolas. Aurélio Castelo Branco enumerou-as: (18)

1) a "Colônia Penal Cândido Mendes" localizada na Ilha Grande. 2) Em Pernambuco, a "Colônia Penal de Itamaracá". 3) Na Baía, o Decréto 11.241, de 6 de fevereiro de 1939, criou o "Reformatório Penal Agrícola" para homens, instalado na Fazenda Pedras Pretas. 4) No Ceará existe a "Colônia Penal de Canafístula". 5) No Rio Grande do Sul, é digna de nota a "Colônia Penal Agrícola General Daltro Filho" 6) A Colônia Agrícola de Taubaté" nascida do idealismo da Acácio Nogueira, que tivemos ocasião de visitar, situada próxima à cidade, confortável e higiênica, onde os detentos cultivam a terra e se dedicam à criação, havendo detentos que residem com suas famílias, em pequenas casas, o que é um passo seguro para a resolução do problema sexual dêsses sentenciados. 7) A "Penitenciária de Neves" em Minas Gerais, a mais importante de nossas penitenciárias agrícolas, nascido do labor fecundo de José Maria Alkmin. É seu próprio criador quem disse que a singularidade da prisão de Neves, não reside nas extraordinariedades de sua construção, mas nas particularidades de seu funcionamento. A Penitenciária é fundamentalmente agrícola, e nas seções industriais trabalham, apenas, aquêles que exerciam atividades industriais, e os que, oferecem perigos de evasão, laborando em trabalhos agrícolas. O pessoal penitenciário de Neves foi recrutado, entre os presos ide melhor comportamento dos presídios próximos. Essas poucas dezenas de condenados destinavam-se a formar uma atmosfera de boa conduta, que se tornasse uma tradição, sem a fôrça ostensiva da vigilância. José Maria Alkmin, com acuidade, não perdia de

(18) AurÉlio C. Branco "Trabalho ao Ar Livre, Colônias Agrícolas e Establecimentos Marítimos" - in "Estudos Penitenciários" — pág. 142 - Ed. Imp. Oficial do Estado - S. Paulo - 1943. 
vista a dignidade do prêso, e lembrando que o prêso é alguém que deve voltar, percebia que é necessário, criar para o sentenciado, um pequeno mundo, semelhante ao mundo dos homens livres, e por isso dizia, focalizando a orientação de Neves:

“Orientamo-nos, principalmente pelo propósito de fazer do mundo penitenciário, uma miniatura do mundo ordinário. Não será possível preparar o homem para a vida em sociedade, privando-o da prática de todos os atos e costumes habituais na coletividade". (19)

Em Neves, nos núcleos agrícolas, distanciados da sede, dedicam-se os detentos à lavoura de cereais, à pomicultura e à horticultura. São os detentos levados às fazendas, conduzidos apenas por um feitor, sem nenhuma vigilância ostensiva. A Penitenciária ocupa-se também da pecuária. Em 1943, já residiam em Neves, cerca de trinta condenados com suas familias. Cumpre dizer, que, quando lá estivemos em 1947, fomos tomados da mesma impressão que Alkmin constatara; a presença da família não diminuia nos condenados a ânsia da liberdade que êles sabiam ser bem mais apreciável. A experiência todavia, como em Taubaté, representavam um passo largo para a solução do problema sexual dos penados. Cumpre ainda relatar, que a penitenciária tem uma importante secção Jurídica, destinada ao estudo da vida pregressa dos condenados, a informação sôbre os detentos ao "Conselho Penitenciário" e a impetração dos recursos de revisão dos processos dos sentenciados. Sôbre a eficiência dêsse serviço de assistência Jurídica, informou José Maria Alkmin, que até 1943, haviam conseguido os detentos deferimento em 281 dos 483 pedidos de revisão dirigidos ao "Egrégio Tribunal de Apelação" O "Conselho Penitenciário" por seu turno, havia

(19) José Maria Alkmin - "Penitenciária Agrícola de Neves" - in "Estudos Penitenciários" - pág. 203 - Ed. Imp. Oficial do Estado - São Paulo - 1943. 
deferido 523 dos 763 pedidos de livramento conuicional, feitos pela secção jurídica da Penitenciária de Neves. Por isso tudo, é sem dúvida, a prisão mineira, um dos mais louváveis aspectos do panorama penitenciário nacional.

\section{As prisões abertas (1) noção - característica - o problema da fuga}

O grande movimento humanizador da pena, fêz com que surgissem as prisões abertas, cuja característica fundamental é desenvolver o senso de responsabilidade do prêso.

A 2. ${ }^{\text {a }}$ secção do Congresso Penal e Penitenciário de Haia de 1950, definiu as prisões abertas — "Estabelecimento aberto designa um estabelecimento penitenciário no qual as medidas preventivas contra a evasão não são constituídas por obstáculos tais como, muros, fechaduras, grades ou guardas suplementares. A característica essencial de um estabelecimento aberto deve assentar-se no fato de se exigir que os prisioneiros se submetam à disciplina na prisão sem uma disciplina estreita e constante, consistindo o fundamento do regime em incutir no prisioneiro o sentimento de responsabilidade pessoal."

Theodolindo Castiglione acha que é condição essencial para a localização do condenado num estabelecimento aberto, o conhecimento da personalidade do criminoso, para que saibam as autoridades penitenciárias se o condenado mere a confiança que nêle será depositada, e se honrará a palavra que empenhou. A essa conclusão chegou aliás o citado congresso de Haia, resolvendo - "dans l'organisation moderne de la justice criminelle, il est hautement désirable, pour servir de base au prononcé de la peine et aux procédures de traitement penitentiaire et de libération,

\footnotetext{
(1) Os técnicos preferem a expressão-estabelecimentos abertos. A questão é de nomenclatura, e despida de importância fundamental.
} 
de disposer d'un rapport préalable au prononcé de la peine et se rapportant non seulement aux circonstances du crime, mais aussi aux facteurs relatifs à la constitution, à la personalité, au caractére et aux antécêdents sociaux et culturels du délinquant".

A seleção deve ser feita rigorosamente, e no caso da inadaptação do prêso ao regime, deve o condenado ser transferido para outro estabelecimento penal diverso. Foi o que decidiu o "Seminário Latino Americano sôbre a prevenção do delito e tratamento do delinquente", reunido no Rio de Janeiro de 6 a 19 de abril de 1953.

A grande vantagem das prisões abertas, é proporcionar ao prêso condições de vida semelhante às da vida em liberdade, preparando-o melhor para a volta ao convívio social. Além disso, atenua as tensões da vida de reclusão. Uma das críticas feitas às prisões abertas, é que propiciam fugas com muito mais facilidade que as prisões fechadas. É de propriedade transcrever o que, a respeito, ensina Noé de Azevedo:

"O assunto que mais preocupa os estudiosos é o que entende com a fuga. As considerações de James V. Bennett, diretor do Bureau de Prisões dos Estados Unidos, nos deixa inteiramente sossegados quanto a êsse risco. Informa, em primeiro lugar, que cêrca de 405 dos sentenciados a cargo do Govêrno Federal, naquele país, estão alojados em estabelecimentos abertos ou trabalham em equipes encarregadas do reflorestamento, construção de estradas e formação de parques. Diz que nos últimos dez anos passaram pelos estabelecimentos penitenciários federais 175.000 delinqüentes. De tôdas as evasões só não puderam ser recapturados 37. Dêstes, 25 eram estrangeiros que tinham entrado clandestinamente no país e que naturalmente voltaram para a sua terra. Assim, apenas 12 não puderam ser recapturados, dando o índice de 1 fugitivo sem recapturação para 17.000 sentenciados".

(20) NoÉ Azevedo - obra citada, pág. 
Pode parecer paradoxal, mas os conhecedores da alma humana, sabem que, via de regra, a palavra empenhada prende mais que as barras de ferro das lucarnas presidiárias.

\section{As prisões abertas - No Estrangeiro e no Brasil}

Nos Estados Unidos o movimento das prisões abertas ganhou amplitude. Em Seagoville, subúrbio de Dallas, há uma prisão aberta com 450 sentenciados. A prisão não possui muros, nem guarda armada, nem grades, e os sentenciados ali se encontram presos exclusivamente por um compromisso de honra. Metade dos sentenciados, está condenada a penas de 5 anos ou menos, cêrca de 100 estão condenados a 10 anos ou mais, e vários estão condenados à prisão perpétua. De cêrca de 2.000 sentenciados, que em 4 anos passaram pela prisão, apenas 6 tentaram fugir. Cinco foram recapturados logo, nas proximidades do estabelecimento, e sòmente a recapturação de um ofereceu dificuldades, sendo afinal o apanhado e recolhido a um estabelecimento fechado.

Em Chino, na Califórnia, em 1947, 750 sentenciados trabalhavam na agricultura e na indústria de carnes e laticínios, presos exclusivamente pelo compromisso de honra assumido.

Na Inglaterra, a idéia teve eco e Leonel W. Fox, presidente da Comissão de Prisões da Inglaterra e do País de Gales, apresentou ao Congresso de Haia um relatório das prisões abertas inglêsas, filiando-as às instituições Borestals.

No Brasil, é possível assinalar a existência de prisões abertas. Magalhães Drumond, lembrado por Theodolindo Castiglione, diz a respeito o seguinte: - "A coisa (verifiquei-o em várias cidades mineiras), faz-se com o assentimento, o aplauso e o auxílio de tôda gente. De dia, os condenados em plena liberdade vão onde queiram, assis- 
tem a atos de cultos religiosos, freqüentam diversões lícitas, são sem desconfiança, recebidos em todos os lares, e podem assim, sem quaisquer obstáculos, ganhar honestamente com que suprir às deficiências da alimentação e vestuário fornecidos pelo Estado. À tardinha, deixando as suas ocupações habituais acorrem apressados à cadeia, para serem postos debaixo de chave até a manhã seguinte." (21)

$\mathrm{Na}$ "Semana Comemorativa do Duodecênio do Código Penal" realizada no Rio de Janeiro, de 10 a 16 de outubro de 1954, tivemos notícia da prisão aberta de "Canasvieiras", em Santa Catarina. Em São Paulo, já se encontra em mãos do govêrno, um projeto de construção de uma prisão aberta, com capacidade para 150 presos, e que deverá ser localizada nas proximidades de Campinas, numa fazenda do Govêrno. Essa prisão aberta será um dos centros de observação de estudos do "Instituto Latino Americano de Criminologia"; na cidade de Martinópolis, no interior do Estado de S. Paulo, já se inicia uma experiência de prisão aberta, e no Rio Grande do Norte desde 1948, na cidade de Sant'Anna dos Matos, há uma prisão aberta. Quando escrito êste trabalho, ainda não existiam no E. de S. Paulo, as notáveis prisões abertas de Baurú, Itapetininga e S. J. do Rio Preto. É forçoso, fazer-se uma referência a elas, nêste momento. Convertendo em 18/7/55, Escolas Agrícolas, inoperantes e deficitárias, em Institutos Penais Agricolas, o govêrno do Estado, deu o mais avançado e largo passo, no sentido da reforma penitenciária. Os Institutos Penais Agrícolas de São Paulo, que são indiscutivelmente prisões abertas, onde se observam todos os requisitos exigidos pelo congresso de Haia, constituem legítimos florões de glória penitenciária, para o Brasil. Neles, a dignidadè do reeducando não é esquecida; neles, o trabalho educa e regenera; neles, não se fazem sentir os corrosivos males da cela. Estabelecimentos abertos sem grades, com ferrolhos, nem trancas, colocam-se à altura dos melhores esta-

(21) Theodolindo Castiglione - Obra citada pág. 13. 
belecimentos abertos do mundo, dentro deles se realizando diuturnamente, uma obra de recuperação que assombra.

\section{0 assunto nos Congressos Penitenciários}

O problema tem sido ventilado em Congressos internacionais. Já o "Congresso da Associação Internacional de Direito Penal", realizado em Bruxelas, em 1926 se ocupava de uma espécie de estabelecimento intermédio entre a prisão fechada, e a que hoje se entende como prisão aberta.

O XII Congresso Penal e Penitenciário Internacional", reunido em Haia, em 1950, cuidou demoradamente do assunto, tendo chegado a importantes conclusões.

O "Seminário Latino Americano sôbre a prevenção do Delito e Tratamento de Delinqüente" reunido sob os auspícios da Organização das Nações Unidas, no Rio de Janeiro, de 6 a 19 de abril de 1953, foi teatro de amplos debates a respeito.

A "IV Jornada Franco-Latino-Americana de Direito Comparado", realizada em S. Paulo, em 1954, incluiu no seu temário as prisões abertas, tendo dois juristas bandeirantes, Noé de Azevedo e Theodolindo Castiglione pronunciado importantes conferências sôbre a matéria.

O tema ventilado nos congressos, peneirado na batéia dos penalistas, analisado e discutido pelos penitenciàristas, já possui uma expressão de alta importância. É interessante, pois, trancrevermos as resoluções de pelo menos um dêsses congressos. Assim é que, o "Seminário Latino Americana sôbre a prevenção do delito e tratamento de delinquentes", decidiu a respeito:

\section{Establecimientos penitenciários abiertos}

1 - Los establecimientos penitenciários abiertos se caracterizan por un régimen de auto-disciplina, por el sen- 
tido de responsabilidad del proprio recluso respecto al grupo en que vive y por la ausencia de precauciones físicas contra la evasión, tales como guardia armada, muros, rejas, cerraduras, etc., régimen que alienta al recluso a hacer uso de la liberdad que se le concede sin abusar de la misma. Son estas las características que distinguen las instituciones abiertas de aquellas dirigidas conforme a los mismos principios si bien éstos no son desarrolados totalmente.

2 - El régimen de vida de los reclusos en los establecimientos abiertos debe aproximarse lo más posible al de la vida en libertad.

3 - Los establecimientos abiertos pueden existir bien como instituciones autónomas o como secciones o dependencias de otro establecimiento.

4 - Según los critérios propios de cada país y la classe de delincuentes destinados a los establecimientos abiertos, los reclusos podrán ingressar en ellos, bien desde el comienzo de la pena, o después de haber cumplido parte de ella en otro tipo de establecimiento.

5 - La admisión de delincuentes en esto tipo de establecimiento, deberá estar basada en un critério de selección que tome en cuenta la aptitud de los reclusos para adaptares ao régimen de la institución y la vataja que éste representa, para favorecer la readaptación social de los reclusos, sobre cualquier tratamiento inherente a otra forma de privación de libertad.

Por lo tanto, este criterio no deberá depender exclusivamente de la condición penal e penitenciária del recluso ni de la duración de la pena.

La seleción as hará sobre la base de un exame médico psicológico y investigación social. En aquellos países ouyes medios lo permiten se recomienda la creación de un instituto $\mathrm{u}$ organismo encargado de hacer la classificación $\mathrm{y}$ seleción de los delincuentes destinados a los establecimientos abiertos. 
6 - Deben ser traslados a otro tipo de establecimiento o allí donde exista, al instituto mencionado en la regla anterior, los reclusos incapaces de adaptarse al tratamiento en un instituto, digo, en un establecimiento abierto o que observen una conducta que afecte desfavorablemente el funcionamiento del estabelecimiento o el comportamiento de otros reclusos.

7 - Las condiciones generales de buen funcionamiento de un establecimiento abierto son las siguientes:

a) Cuando el establecimiento esté situado en el campo su aislamiento no debe ser tal que constituya un inconveniente para el personal o un obstáculo a los fines asignados al establecimiento.

b) Aunque el trabajo agrícola es de gran ventaja también se deben organizar talleres industriales y de adiestramiento o vocacional.

c) Dado que la readaptación de los reclusos sobre la base de régimen de confianza, depende dela influencia de los miembros del personal y conocimiento individual que estos tengan del carácter y de las necessidades especiales de cada recluso, el personal deberá posoer una formación técnica especial.

d) Por la misma rázón, él numero de los reclusos deberá mantenerse dentro de limitos que permitan al diretor del establecimiento y al personal superior tener ese conocimiento de los reclusos.

e) El público en general y mas especialmente las poblaciones vecinas, deben ser informados de los fines e métodos de cada establecimiento abierto. A tal afecto, podria ser extremamente beneficioso obtener la prensa especialmente de local.

8 - Si bien los establecimientos abiertos supoben mayores facilidades de evasión y para hacer mal uso de las relaciones con el mundo exterior, presentan vantajas sobre Jos otros tipos de establecimientos, por las razones siguientes: 
a) Son más favorables a la salud física y mental de los reclusos.

b) La flexibilidad inherente al régimen de establecimientos abiertos, se traduce en una mitigación de las reglas atenía las tensiones de la vida de reclusión y conduce, asi, a un mejoramiento de la disciplina. Además, la asuencia de coación material, o física y las relaciones de mayor confianza entre los reclusos e el personal, tienden a crear condiciones propicias para un sincero deseo de readaptación social.

c) Las condiciones de vida en los establecimientos abiertos, se allan más proximas qua las de ningún otro a las de la vida en liberdad. Las relaciones con el mundo exterior pueden ser más facilmente mantenidas creando así en el recluso el sentimiento de que no se halla aislado de la sociedad. En este aspecto y como ejemplos pueden organizarse: -- paseos en grupos, competencias esportivas con equipos del exterior y aún permisos inidividuales especialmente destinados a mantener los lazos familiares.

d) La misma medida es menos onerosa en un establecimiento de otro tipo, especialmente si se toma en cuenta que los gastos de construccion son, más reducidos $\mathrm{y}$, en caso de exploración agrícola, la producción es más elevada.

La opinión pública debe tener en cuenta que este sistema impone al recluzo un esfuerzo moral considerable.

9 - En conclusión, el Seminário Latineamericano, estima que:

a) la aplicación del regimen de establecimientos abiertos al mayor numero posible de reclusos debe ser conforme a las condiciones establecidas en la regla 5 y las concernientes al personal según el inciso $c$ de la regla 7;

b) el sistema de establecimientos abiertos puede ayudar a resolver el problema de las penas cortas de privación de libertad.

c) la formación de estadistica permitiria la avalación de la reincidencia y de la readaptación social en los establecimientos abiertos. 


\section{Conclusão}

O regime das prisões abertas é altamente recomendável, pois não anula a personalidade do delinqüente, nem lhe diminui a dignidade. Trata-o humanamente, estimulando-o á regeneração, não fazendo dêle pasto de vingança, mas vendo-o como um doente que precisa ser tratado compreensivamente. Claro é, que o regime não deve ser aplicado a todos os condenados. Deverá haver uma seleção feita por institutos adequados, dos quais os merecedores do previlégio da prisão aberta. É possivel, que no futuro possam todos os estabelecimentos penitenciários serem prisões abertas. Dependerá isso do resultado da experiência, que poderá a muitos olhos parecer utópica, ou, poética, mas que merece e precisa ser tentada, lembrando todos, que só o amor constrói para a eternidade, que o homem é irmão do homem, e que, aquêle que um dia voltará ao nosso convívio, precisa ser convenientemente preparado para êsse regresso. 